\title{
Coronavirus: online GP bookings should be stopped because of safety risks, warns BMA
}

\author{
Elisabeth Mahase
}

The BMJ

General practices should be able to turn off their online booking systems in response to the covid-19 outbreak without fear of repercussions over breaching their contract, the BMA has told NHS England.

Practices are contractually obliged to provide $25 \%$ of their appointments through online booking; as this system does not triage patients in the same way that a receptionist does, however, the BMA has warned that it could lead to patients who have potentially contracted coronavirus turning up at the practice. This would put both staff and other patients at risk.

Current government advice for patients with potential symptoms, or who are concerned because of relevant travel history, is to call NHS 111 rather than going to hospital or their GP practice. As of 12 February, a total of 1758 people have been tested for the virus in the UK, of which 1750 were confirmed negative and eight positive. Two of those infected are believed to be GPs from a practice in Brighton, which has been temporarily closed. Speaking to The BMJ, BMA GP Committee member Peter Holden said, "It's clear that a hole in the system has occurred. The whole coronavirus triaging system is dependent on people not coming and potentially contaminating the estate and infecting patients and healthcare workers needlessly. The online booking of appointments was, unfortunately, overlooked.

"The BMA are asking the government if, in the interests of patient safety and preservation of the service, we can switch off online booking.

"At the moment, in theory, a practice would be in breach of its contract if it stopped providing online booking, but it would be foolish for anyone to challenge them on that. Online booking is about patient convenience, not safety, and safety has to come first. We also have a duty to our staff and our other patients."

The UK government officially declared the coronavirus outbreak a "serious and imminent threat to public health" on 10 February. ${ }^{1}$ As part of this, NHS staff members were given "strengthened powers" to keep patients in isolation where necessary.

Mahase E. Coronavirus: NHS staff get power to keep patients in isolation as UK declares "serious threat". BMJ 2020;368:m550. 10.1136/bmj.m550 32041792

Published by the BMJ Publishing Group Limited. For permission to use (where not already granted under a licence) please go to http://group.bmj.com/group/rights-licensing/ permissions 